\title{
Discussion on Teaching Reform of AutoCAD Courses in Architectural Engineering Specialty Based on the Cultivation of Applied Innovative Ability
}

\author{
Shaoju Hao \\ Henan Radio and Television University \\ Zhengzhou, China
}

\author{
Hansong Yang \\ Huanghe Science and Technology College \\ Zhengzhou, China
}

\begin{abstract}
Applied innovation talents training should lay emphasis on students' practical ability cultivation. AutoCAD is not only the specialized core course of architectural engineering specialty but a highly practical course. Through combining the present using characteristic of AutoCAD in construction industry, AutoCAD curriculum system and the existing problems in actual teaching are perfected, teaching contents and methods of architectural CAD suitable for applied innovation talents cultivation are put forward.
\end{abstract}

Keywords—applied; innovation ability; teaching reform

\section{INTRODUCTION}

In recent years, the higher education of China has entered into the phase of mass education, and the society has a wide need for applied talents. The applied talents of architectural engineering in China should master the engineering technical knowledge of their professional field, accept the basic production engineering practice training, and have strong practical ability so that they can be talents engaging in the design, construction and management of architectural engineering project. Under the background of the modern information era, the design, construction and management of architectural engineering project are done by computer graphics. Currently, AutoCAD is the most widely used computer graphics software in construction industry. As an applied innovation talent of architectural engineering specialty, skillfully using AutoCAD to draft is the basic technical applying ability. Almost all universities in China have set up computer graphic courses. AutoCAD, being the preferred software for learning, still has many problems which are mainly manifested in the following two points: firstly, AutoCAD, as a practice based curriculum, can enable students to learn while training, which is a good teaching arrangement; however, due to enrollment expansion of colleges in recent years, hardware configuration obviously lags behind the growth rate of students and schools' computer rooms cannot satisfy the teaching mode of making students learn while exercising, so that only multimedia classroom is arranged for concentrating on AutoCAD theories teaching in mixed classes, and then allow students to operate in the computer room by small classes; all these lead to operation's being behind theories and students' failure to immed iately apply theories in computer operation. Secondly, without combing with other professional courses, curriculum design and graduation design, AutoCAD course is finished after examination; however, students still cannot address problems that they meet in using AutoCAD software in their professional course assignment, curriculum design and graduation design. Therefore, how to design an AutoCAD course is very necessary to be deeply considered.

\section{INT RODUCTION OF PROFESSIONAL AUTOCAD COURSES}

CAD, namely computer aided design, refers to use computer system to aid a design's establishment, drafting, analys is and optimization. AutoCAD is the most widely used CAD software with a powerful function, easy learning and using and user-friendly interface as well as an opening structure. Hence, based on AutoCAD, a group of specialized software suitable for Chinese technicians is secondly developed, for instance, Tianzheng CAD, Zhongwang CAD, Lizheng CAD, Xiangyuankonggui CAD, etc. And they are extensively used in the construction industry of China. Since they are developed on the basis of AutoCAD, these more specialized software is easy to master as long as know the using method of AutoCAD well. As an applied innovation talent of architectural engineering specialty, students must be an expert in using the graphics software of their own specialty. Because the length of schooling of architectural engineering specialty is three years, so it is impossible to teach all specialty-related graphics software. Thus, it is essential to master the mostly basic graphics software - AutoCAD. In accordance with the characteristics of applied innovation talents, the teaching goal of AutoCAD courses in architectural engineering specialty is that: through studying this course, students should basically master AutoCAD technology and its application to architectural engineering field, be able to employ AutoCAD to design construction drawings of building or structure which conforms to Standard for House Construction Drawing, and know Tianzheng CAD and Zhongwang CAD developed on the bas is of AutoCAD.

\section{TEACHING CONTENT DESIGN OF AUT OCAD COURSES IN ARCHITECTURAL ENGINEERING SPECIALTY}

Teaching content design is an important part of curriculum design, and its rationality directly decides the rationality of curriculum design. Selecting suitable teaching content is a 
critical factor in successful teaching. Engineers are experts of his industry, and the innovation of engineering science \& technology increasingly needs these experts with profound professional knowledge and rich professional practical experiences. Since modern technology involves an expanded specialty scope, strong comprehensiveness and quickly updated knowledge, it is necessary for engineering talents to display their exploration and fighting spirit in full measure and also to exert team's cooperation spirit. Due to AutoCAD's huge system and various command, students should master the method of drafting building and structure construction drawing by using AutoCAD in the limited credit hours through curriculum learning, meanwhile, attach attention to students' problem analyzing and solving ability as well as applied innovation ability in designing teaching content. The content of AutoCAD course usually includes the basic operation of AutoCAD, the drawing command, modification command, text and dimension marking, and environment setting of 2D graphics and so on. Reform the teaching contents according to problems existing in teaching,

\section{A. Taking Problem Solving as a Starting Point in Designing Teaching Content}

Generally, AutoCAD follows the prescribed order to learn from the basics like drawing command and modification command when organize the teaching content, and lastly applies these commands to relevant specialties, which not only takes too much credit hour but also making students feel complex and boring about the learning. Therefore, the characteristics of architectural engineering specialty should be taken into account in teaching content design, and take problem solving as a starting point to study AutoCAD commands, so that credit hours are greatly reduced and students truly master the application of AutoCAD to architectural engineering. While organize teaching content, take problem as unit, for instance, problems like drawing frame, stairs, window elevation, reinforcement drawing, staircase detail drawing, architectural plan, architectural elevation, etc. Students are required to address problems through AutoCAD, and then they will fast apply AutoCAD to specialized field. "Table I" and "Table II" are parts of AutoCAD teaching, and they are aiming to solve problems of drawing architectural plan and architectural elevation.

TABLE I. ARCHITECTURAL PLAN DRAFTING

\begin{tabular}{|c|c|c|c|c|}
\hline SN & Item & Attention & Score & Cre dit Hour \\
\hline 1 & Layer & $\begin{array}{l}\text { The selection of } \\
\text { color, line width and } \\
\text { line type }\end{array}$ & 20 & \multirow{5}{*}{$\begin{array}{l}\text { Eight credit } \\
\text { hours } \\
\text { (hereinto six } \\
\text { credit hours } \\
\text { for computer } \\
\text { operation) }\end{array}$} \\
\hline 2 & $\begin{array}{l}\text { Wall, door and } \\
\text { window }\end{array}$ & $\begin{array}{l}\text { Use of ML and its } \\
\text { modification }\end{array}$ & $\begin{array}{l}40 \\
40\end{array}$ & \\
\hline 3 & $\begin{array}{l}\text { Balcony, stair, } \\
\text { apron, etc. }\end{array}$ & $\begin{array}{l}\text { Classification } \\
\text { detailed layer }\end{array}$ & $\begin{array}{l}10 \\
10\end{array}$ & \\
\hline 4 & $\begin{array}{l}\text { Dimension } \\
\text { marking }\end{array}$ & $\begin{array}{l}\text { Setting of marking } \\
\text { pattern }\end{array}$ & $\begin{array}{l}20 \\
20\end{array}$ & \\
\hline 5 & $\begin{array}{l}\text { Compass, wind } \\
\text { rose and } \\
\text { drawing frame }\end{array}$ & $\begin{array}{l}\text { Draw according to } \\
\text { specification }\end{array}$ & $\begin{array}{l}10 \\
10\end{array}$ & \\
\hline
\end{tabular}

TABLE II. ARCHITECTURAL ELEVATION DRAFTING

\begin{tabular}{|c|c|c|c|c|}
\hline $\mathbf{S N}$ & Item & Attention & Score & $\begin{array}{l}\text { Credit } \\
\text { Hour }\end{array}$ \\
\hline 1 & \begin{tabular}{ll}
\multicolumn{2}{c}{ Outdoor flooring } \\
line and locating \\
axis
\end{tabular} & $\begin{array}{l}\text { The selection of } \\
\text { line width and line } \\
\text { type }\end{array}$ & $\begin{array}{l}15 \\
15\end{array}$ & \\
\hline 2 & Door and window & Use of array & $\begin{array}{l}35 \\
35\end{array}$ & $\begin{array}{l}\text { Six credit } \\
\text { hours }\end{array}$ \\
\hline 3 & $\begin{array}{l}\text { Balcony, pillar, } \\
\text { wall and rainwater } \\
\text { pipe }\end{array}$ & Set good layer & $\begin{array}{l}15 \\
15\end{array}$ & $\begin{array}{l}\text { (hereinto } \\
\text { four credit } \\
\text { hours for }\end{array}$ \\
\hline 4 & Roof & $\begin{array}{l}\text { Cornice, skylight, } \\
\text { chimney and air } \\
\text { hole }\end{array}$ & $\begin{array}{l}20 \\
20\end{array}$ & $\begin{array}{l}\text { computer } \\
\text { operation) }\end{array}$ \\
\hline 5 & Dimension marking & Elevation & $\begin{array}{l}15 \\
15\end{array}$ & \\
\hline
\end{tabular}

Through the method of solving problems, students can soon be able to draw specialized drafting by using AutoCAD, simultaneously, students' ability of reading engineering drafting is trained. Mixing typical questions appearing in curriculum design with teaching content helps students solve problems in advance.

\section{B. Design Teaching Content by Combining Drawing Standard}

In the first semester, architectural engineering specialty will open architectural drawing courses, but not professional courses or curriculum design. Thus, when drawing, students are strangers to drawing standard, so that problems such as drafting lines regardless of thickness, random font and word size, non-standard dimension marking and so on will occur. Repeatedly stress the drawing standardization and combine with relevant regulations of Unified Standard for Building Drawings ( GB/T 50001-2001) and Standard for Architectural Drawings (GB/T 50104-2001) to increase students' consciousness of closely combining AutoCAD with engineering drawing knowledge and specification. "Table III" and "Table IV" take dimension marking and font as examples to require students to set dimension marking pattern and font style according to drawing standard.

TABLE III. SET MARKING PATTERN

\begin{tabular}{|c|c|c|c|c|c|}
\hline Item & Setting & Item & Setting & Item & Setting \\
\hline $\begin{array}{l}\text { Baseline } \\
\text { spacing }\end{array}$ & $7 \sim 10 \mathrm{~mm}$ & $\begin{array}{l}\text { Offset } \\
\text { from origin }\end{array}$ & $2 \mathrm{~mm}$ & $\begin{array}{l}\text { Dimension } \\
\text { text height }\end{array}$ & $3.5 \mathrm{~mm}$ \\
\hline $\begin{array}{l}\text { Beyond } \\
\text { dimensio } \\
\text { n-line }\end{array}$ & $2 \mathrm{~mm}$ & $\begin{array}{l}\text { Linear } \\
\text { dimension } \\
\text { arrow form }\end{array}$ & $\begin{array}{l}\text { Buildin } \\
\mathrm{g} \\
\text { markin } \\
\mathrm{g}\end{array}$ & $\begin{array}{l}\text { Overall } \\
\text { Scale }\end{array}$ & $\begin{array}{l}\text { Accord } \\
\text { with } \\
\text { plot }\end{array}$ \\
\hline
\end{tabular}

TABLE IV. SET TEXTPATTERN

\begin{tabular}{llllll}
\hline Item & Setting & Item & Setting & Item & Setting \\
\hline $\begin{array}{llllll}\text { shx } \\
\text { font }\end{array}$ & gbeitc & $\begin{array}{l}\text { Big } \\
\text { font }\end{array}$ & gbcbig & Width factor & 0.7 \\
\hline
\end{tabular}

C. Brief Introduction of CAD $3 D$ Command

At present, computer 3D building performance is riddled in architectural industry for it being seen in planning, construction and management. Therefore, just introducing 2D command in CAD courses cannot satisfy the needs any more. Under the basis of limited credit hours, briefly introduce some 
3D command can usher students to computer 3D building performance. Henceforth, let students interested in learning computer 3D building performance to lay the foundation through selected courses or self education. Computer 3D building performance mainly includes architectural renderings, architectural animation, visual reality (VR) and building information modeling (BIM). No matter what kind of type, architectural modeling is a must. Students can make 2D drawing have height and then become 3D model through CHPROP command on the basis of CAD 2D drawing. Besides modeling through AutoCAD, 3dsMax, SketchUp and other software can model as well. Students' learning interest is inspired. And encourage them to study harder after class through introducing the functions and interrelationship of each software.

\section{TEACHING MOdE AND MET HOD DESIGN OF AUTOCAD COURSE S IN ARCHITECTURAL ENGINEERING SPECIALTY}

After the expansion of college enrollment, obviously, hardware facilities can't keep up with the growth rate of the students. On AutoCAD courses, tension computer rooms, notsufficient computers and lacking experimental teachers are prominent problems. Generally, the credit hours of AutoCAD courses are about 32 which is less and can be completed in eight weeks. Therefore, when arrange courses, a semester can be divided first and second period, with some classes learning in the first period and the others learning in the second period, so that the problems of computer room tension and insufficient teachers are solved. What's more, the author found that, in AutoCAD teaching, the first barrier in students' AutoCAD learning is computer application. Although computers have a high penetration rate, some students still have little or no access to the computer. They just use computers when learning basic computers, which leads to teachers' introduction of computer basic applying knowledge when teaching AutoCAD. But for students who know computers well, this kind of basic computer teaching is pointless. Thus, on course arrangement, AutoCAD courses can be taught according to students' computer skills but not class teaching. Divide students' computer skills into Grade A and Grade B, or let students choose the level according to their own computer application ability. Students with good computer application skills are one grade while students with poor computer application skills are the other grade. In this way, the teaching content arrangement can be different so as to make more students feel easy and nonboring for course content.

On teaching method, due to the particularity of AutoCAD's high practice, specific cases cannot be left alone no matter in theory teaching or teaching on computers. This echoes with teaching content design which regards problem-solving as starting point, and adapts to the characteristics of AutoCAD courses. According to different teaching content, choose suitable cases and assign matching and moderate exercises to make students skillfully master AutoCAD software.

\section{REFERENCES}

[1] Y.F. Wang, L. Yan, J. Li. Reform and Exploration in the Teaching of CAD Aut o. Chemical Engineering \& Equipment. 2015 Vol. 29.
[2] L. P. Liu, H. Ye. Techniques and Applications of AutoCAD Graphics in Teaching. Computer Knowledge and Technology. 2015 Vol. 33.

[3] X. L. Li, T. H. Duan. Research on the Teaching of AutoCAD Courses Combined with Professional Application. Education Teaching Forum. 2015 Vol. 14.

[4] Q. ZH. Wu. Talking about the Teaching Reform of Architectural CAD Course. Shanxi Architecture.2014 Vol. 15.

[5] X. Y. Yang. Application Analysis of Architectural Drawing Based on AutoCAD. Electronic Test. 2014 Vol. 18. 